\title{
Formation of hydrogen peroxide in normal and copper- treated rat endometrium
}

\author{
R. K. Johri and P. R. Dasgupta \\ Division of Endocrinology, Central Drug Research Institute, Lucknow-226001, India, and \\ Department of Obstetrics and Gynecology, Postgraduate Institute of Medical Education and \\ Research, Calcutta-700020, India
}

\begin{abstract}
Summary. An intrauterine copper device stimulated endogenous hydrogen peroxide formation in whole homogenates and in the mitochondrial and microsomal (but not the nuclear) fractions of rat endometrial tissues. Uric acid also accumulated in the endometrium of copper-treated rats, but not in those fitted with a nylon device or sham operated. It is suggested that the contraceptive effect of copper may be related to these events.
\end{abstract}

\section{Introduction}

The efficacy of a copper intrauterine contraceptive device (Cu-IUCD) has been suggested to be due, in part, to the chemical reactions associated with the dissolution of the metal (Oster, 1971, 1972). Oster \& Oster (1974) showed that the metal passed from the cuprous to the cupric state when a strip of metallic copper was immersed in physiological saline in vitro and this change was accompanied by the production of free hydroxyl radicals $(-\mathrm{OH})$, which could combine to form hydrogen peroxide. Moreover, some of the metallic copper is consistently absorbed and widely distributed in different organs, including the uterus, within hours after insertion of the device (Okereke, Sternleib, Morell \& Scheinberg, 1972; Moo-Young, Tatum, Brinson \& Hood, 1973; Salaverry, Mendez, Zipper \& Medel, 1973; Moo-Young \& Tatum, 1974; Ranney et al., 1975), thus disturbing the normal concentration of the copper in the cell (Hernandez, Aznar, Hicks, Ballesteros \& Rosado, 1975).

Since high concentrations of hydrogen peroxide are known to exert potent denaturing effects upon a number of cell constituents such as proteins, nucleic acids and lipids (Tucker \& Grisolia, 1962; Amelunxen \& Grisolia, 1962; Pihl \& Lange, 1962; Roubel \& Tappel, 1966; Nofre \& Cier, 1967; Menzel, 1970), the presence of hydrogen peroxide in the uterine milieu may be significant with regard to the mode of contraceptive action of metallic copper. In the present study we therefore investigated the manner and extent of copper-induced peroxide formation in the rat endometrium.

\section{Materials and Methods}

The rats used were albinos from the Institute colony and were maintained under uniform husbandry conditions. The females were healthy virgins, 90 days of age and animals in the control and experimental groups were matched for body weight $(160 \pm 15 \mathrm{~g})$.

Pieces of pure copper wire $\left(0.2 \mathrm{~mm}\right.$ diameter; $12.6 \mathrm{~mm}^{2}$ area) were fitted bilaterally into the lumen of the uterine horns of animals in Group C. Nylon sutures of the same area and diameter 
were similarly inserted into Group B rats. The control animals of Group A were sham operated; a device was inserted through the uterine lumen (about $1 \mathrm{~cm}$ ) but was not left in the uterine lumen. All the surgical procedures were carried out under aseptic conditions.

After 30 days the animals were killed during oestrus and the uterine horns were dissected out. The endometrial scrapings were collected as previously described (Dasgupta, Pandey, Garg, Srivastava \& Kar, 1972). The tissue was kept in ice-cold isotonic sucrose solution ( $0.25 \mathrm{M})$ prepared in glass-distilled water. The tissue was homogenized at moderate speed in a motor-driven all-glass homogenizer for $10 \mathrm{~min}$ with occasional stops. Homogenates with a protein concentration of $50 \pm 4 \mathrm{mg}$ were used. Subcellular fractions were obtained according to the method of Schneider (1948).

\section{Measurement of hydrogen peroxide}

Scopoletin, a fluorescent substrate, was used to measure hydrogen peroxide according to the method of Andrae (1955) in a spectrophotofluorometer (Aminco-Bowmann) at $395 \mathrm{~nm}$ excitation and $465 \mathrm{~nm}$ emission wavelengths. Sensitivity was set at 39 and the photomultiplier slit adjusted at 0.5 . The reaction was followed at $30-\mathrm{sec}$ intervals for $4 \mathrm{~min}$ and the rate of hydrogen peroxide formed was calculated from straight-line portions of the curves.

The assay system consisted of $2.0 \mathrm{ml}$ whole homogenate or subcellular fractions (as a source of hydrogen peroxide); $0.5 \mathrm{ml}$ scopoletin $(40 \mu \mathrm{mol} / \mathrm{ml})$ in $0.05 \mathrm{M}$-phosphate buffer $(\mathrm{pH} 8.0) ; 0.2$ $\mathrm{ml}$ aqueous horseradish peroxidase $(100 \mu \mathrm{g} / \mathrm{ml}) ; 20 \mu \mathrm{M}$-sodium azide (as an inhibitor of tissue catalase); and phosphate buffer to give a total volume of $3.0 \mathrm{ml}$. Controls were prepared identically but tissue fractions were omitted. The enzyme solution was added last to start the reaction. Substrates such as alanine, histamine and uric acid were added separately to the mitochondrial fractions to give a concentration of $5.0 \mathrm{~mm}$ in the reaction mixture. Protein-free supernatants of the tissue homogenates were also obtained by treatment with $5 \%(\mathrm{w} / \mathrm{v})$ trichloroacetic acid and $0.1 \mathrm{ml}$ of these supernatants was added to the reaction mixture containing mitochondria. For these assays, the reaction mixture without these additional substrates served as control. In microsomal fractions, $40 \mu \mathrm{mol}$ phosphate, $20 \mu \mathrm{mol} \mathrm{MgCl}_{2}$ and $40 \mu \mathrm{mol}$ NADPH or NADH were added: NADPH/NADH was excluded from the control reactions.

The TCA-treated supernatants were analysed for the presence of uric acid according to the method of Stimson \& Reuter (1943).

Protein was determined by the method of Lowry, Rosebrough, Farr \& Randall (1951).

Scopoletin was obtained from K \& K Laboratories, U.S.A., and horseradish peroxidase (minimum activity 3000 units $/ \mathrm{mg}$ ) from Worthington Biochemical Corporation, U.S.A. All other chemicals were of high purity reagent grades.

\section{Results}

The whole homogenates as well as all the subcellular fractions except that of nuclei produced hydrogen peroxide; maximal activity being present in the mitochondrial fraction. Values for endometria in Group C were significantly higher $(P<0.05)$ than those in Groups A and B (Table 1). This was also found for all 3 substrates and supernatants tested (Table 2). Responses of Group B endometria were similar to those of Group A. The protein-free supernantant of Group $C$ endometria (which contained $11.8 \pm 2.8 \mathrm{mg}$ uric acid/g tissue) also enhanced the rate of hydrogen peroxide formation. The uric acid contents of the supernatant fractions of Groups $A$ and $B$ were low $(1.9 \pm 0.3$ and $2.2 \pm 0.5 \mathrm{mg} / \mathrm{g}$ tissue respectively) and they did not affect hydrogen peroxide production. 
Table 1. Rate of hydrogen peroxide production in rat endometrium $(\mathrm{nmol} / \mathrm{min}$ per mg protein)

\begin{tabular}{lccc}
\hline \multicolumn{1}{c}{ Fractions } & $\begin{array}{c}\text { Group A } \\
\text { (control) }\end{array}$ & $\begin{array}{c}\text { Group B } \\
\text { (nylon) }\end{array}$ & $\begin{array}{c}\text { Group C } \\
\text { (copper) }\end{array}$ \\
\hline Whole tissue & $0.09 \pm 0.03$ & $0.08 \pm 0.02$ & $1.3 \pm 0.3^{*}$ \\
Nuclei & 0.0 & 0.0 & 0.0 \\
Mitochondria & $0.13 \pm 0.03$ & $0.12 \pm 0.02$ & $3.8 \pm 0.6^{*}$ \\
Microsomes & $0.10 \pm 0.02$ & $0.11 \pm 0.03$ & $1.8 \pm 0.2^{*}$ \\
Supernatant & $0.05 \pm 0.01$ & $0.04 \pm 0.02$ & $0.19 \pm 0.2^{*}$ \\
\hline
\end{tabular}

Vajues are mean \pm s.e.m. from 4 replicate estimations. Each estimation was for a tissue sample pooled from 5 animals (10 uterine horns). U test).

* Significantly higher than values in Groups A and B, $P<0.05$ (Mann-Whitney

Table 2. Effect of substrates on the mitochondrial hydrogen peroxide production in rat endometrium ( $\mathrm{nmol} / \mathrm{min}$ per $\mathrm{mg}$ protein)

\begin{tabular}{lccc}
\hline \multicolumn{1}{c}{ Additions } & $\begin{array}{l}\text { Group A } \\
\text { (control) }\end{array}$ & $\begin{array}{c}\text { Group B } \\
\text { (nylon) }\end{array}$ & $\begin{array}{l}\text { Group C } \\
\text { (copper) }\end{array}$ \\
\hline $\begin{array}{l}\text { None (endogenous } \\
\text { substrates) }\end{array}$ & $0.14 \pm \mathbf{0 . 0 2}$ & $.0 \cdot 13 \pm 0.01$ & $3.9 \pm 0.5^{*}$ \\
Alanine & & & \\
Histamine & $0.25 \pm 0.03$ & $0.24 \pm 0.08$ & $15.5 \pm 2.7^{*}$ \\
Uric acid & $0.44 \pm 0.08$ & $0.41 \pm 0.07$ & $24.2 \pm 8^{*}$ \\
Supernatant of Group C & $0.41 \pm 0.05$ & $0.41 \pm 0.05$ & $24.2 \pm 3.0^{*}$ \\
Supernatant of Group B & $0.37 \pm 0.04$ & $0.34 \pm 0.04$ & $16.2 \pm 3.0^{*}$ \\
Supernatant of Group A & $0.18 \pm 0.01$ & $0.13 \pm 0.02$ & $4.7 \pm 1.0^{*}$ \\
\hline
\end{tabular}

Values are mean \pm s.e.m. from 4 replicate estimations. Each estimation was for a tissue sample pooled from 5 animals (10 uterine horns).

* Significantly higher than values in Groups A and B, $P<0.05$ (Mann-Whitney U test).

Production of hydrogen peroxide by microsomal fractions was stimulated by the addition of reduced NADP or NAD to the reaction mixture, and the values in Group $C$ were higher $(P<$ 0.05 ) than those in Groups A and B (Table 3).

Table 3. Effect of NADPH or NADH on the microsomal hydrogen peroxide production in rat endometrium ( $\mathrm{nmol} / \mathrm{min}$ per $\mathrm{mg}$ protein)

\begin{tabular}{lccr}
\hline \multicolumn{1}{c}{ Additions } & $\begin{array}{l}\text { Group A } \\
\text { (control) }\end{array}$ & $\begin{array}{l}\text { Group B } \\
\text { (nylon) }\end{array}$ & \multicolumn{1}{c}{$\begin{array}{c}\text { Group C } \\
\text { (copper) }\end{array}$} \\
\hline $\begin{array}{l}\text { None (endogenous } \\
\text { substrates) }\end{array}$ & $0.12 \pm 0.03$ & $0.13 \pm 0.02$ & $1.8 \pm 0.05^{*}$ \\
NADPH & $0.25 \pm 0.04$ & $0.29 \pm 0.05$ & $10.4 \pm 1.9^{*}$ \\
NADH & $0.18 \pm 0.01$ & $0.19 \pm 0.02$ & $2.9 \pm 0.3^{*}$ \\
\hline
\end{tabular}

Values are mean \pm s.e.m. from 4 replicate estimations. Each estimation was for a tissue sample pooled from 5 animals ( 10 uterine horns). U test).

* Significantly higher than values in Groups A and B, $P<0.05$ (Mann-Whitney

\section{Discussion}

The production of hydrogen peroxide has been demonstrated in various isolated systems such as respiring micro-organisms (Chance, 1952), perfused rat liver (Sies \& Chance, 1970) and phagocytosing polymorphonuclear leucocytes (Paul \& Sbarra, 1968), suggesting that peroxide 
formation is a physiological event in living organisms (Oshino \& Chance, 1973). Similar observations have been reported for subcellular fractions (Jenson, 1966; Hinckle, Butow, Racker \& Chance, 1967; Sies \& Chance, 1970; Loschen, Flohe \& Chance, 1971).

Hydrogen peroxide is one of the major end-products in the reactions involving oxidations of biologically active amines and uric acid catalysed by flavoproteins, which are localized mainly in the mitochondria (Frieden, Osaki \& Kobayashi, 1965; Dixon, 1971). However, an NADPHdependent oxidase has been shown to be the microsomal hydrogen peroxide generator (Gillette, Brodie \& $\mathrm{La} \mathrm{Du}, 1957$ ). Our results therefore indicate that intrauterine copper could exert a catalytic effect upon these enzyme systems and stimulate the mitochondrial and microsomal production of hydrogen peroxide. The intrauterine copper $T$ device is associated with a significant increase in the copper levels of various subcellular fractions of human endometrium (Hernandez et al., 1975) and therefore an effect of copper on the hydrogen peroxide-producing enzyme systems might be expected.

Uricase, an enzyme which brings about the decomposition of uric acid, is inhibited by high concentrations of metallic copper (Baum, Hubscher \& Mahler, 1956). However, a free metal-catalysed oxidation of uric acid produced stoichiometric amounts of hydrogen peroxide (Frieden et al., 1965), perhaps explaining the peroxide formation occurring after additions of uric acid or supernatants of copper-treated tissue, which contained large amounts of uric acid, to the reaction mixture. It is possible that in untreated (or nylon-treated) endometria uric acid is normally eliminated by uricase, but in the presence of copper this enzyme is inhibited and uric acid accumulates. The concentration of uric acid is increased in the uterine fluid of women with an IUCD in situ (Dasgupta, Kar \& Engineer, 1971).

Copper has also been shown to have an important inductory effect on the xanthine oxidase activity of rat liver and kidney (Kovalsky \& Vorotnitskaya, 1970) and augmentation of the activity of this enzyme would stimulate the breakdown process of purines to accentuate the formation of uric acid. If this also happens in the endometrium, a high rate of peroxide production in copper-treated animals may be due to a catalytic effect of the metallic copper upon enzymic oxidations and to certain closely related $\mathrm{Cu}$-ion catalysed oxidations.

The production of hydrogen peroxide much above its physiological level is likely to affect tissue metaboism, since this biochemical feature is related to several biological phenomena such as oxygen poisoning, and radiosensitivity (Menzel, 1970). Peroxide is known to be a powerful inhibitor of sulphydryl group-dependent enzymes (Tucker \& Grisolia, 1962; Amelunxen \& Grisolia, 1962; Pihl \& Lange, 1962; Roubel \& Tappel, 1966). It denatures protein (Roubel \& Tappel, 1966) and nucleic acids (Nofre \& Cier, 1967) and causes the destruction of amino acids (Roubel \& Tappel, 1966) which may result in cell damage. The consequences of lipid peroxidation are also disastrous for the cell (Menzel, 1970). The peroxide-induced changes in the biochemical composition of rat endometrium may create an unfavourable environment in the uterine milieu in the presence of an intrauterine copper device. This may be one of the factors responsible for the contraceptive and pharmacological action of metallic copper in the uterus.

Although a high concentration of hydrogen peroxide and free radicals may be relevant to the long-term safety of $\mathrm{Cu}$-IUD wearers, there is no clinical evidence of neoplasia caused by copper and the $\mathrm{Cu}$-IUD is considered safe. Catalase and certain reducing agents present endogenously would probably protect the tissue from peroxide damage of the cell and these factors would in any case be rate limiting. The values obtained in these experiments could therefore be considered as being at the upper limit.

\section{References}

Amelunxen, R. \& Grisolia, S. (1962) The mechanism of triosephosphate dehydrogenase inactivation by reduced diphosphopyridine nucleotide, J. biol. Chem. 237, 3240-3245. 
Andrae, W.A. (1955) A sensitive method for the estimation of hydrogen peroxide in biological materials. Nature, Lond. 175, 859-861.

Baum, H., Hubscher, G. \& Mahler, R.H. (1956) Studies on uricase. II. The enzyme substrate complex. Biochim. Biophys. Acta 22, 414-417.

Chance, B. (1952) The state of catalase in the respiring bacterial cell. Science, N.Y. 116, 202-203.

Dasgupta, P.R., Kar, A.B. \& Engineer, A.D. (1971) Uric acid in the uterine fluid of women fitted with Lippes loop and in deposits found on used devices. Am. J. Obstet. Gynec. 110, 593-594.

Dasgupta, P.R., Pandey, J.K., Garg, R., Srivastava, K. \& Kar, A.B. (1972) Effect of a copper intrauterine contraceptive device on enzyme activity on the rat endometrium. Contraception 6, 459-464.

Dixon, M. (1971) The acceptor specificity of flavins and flavoproteins. III. Flavoproteins. Biochim. Biophys. Acta 226, 269-284.

Frieden, E., Osaki, S. \& Kobayashi, H. (1965) Copper proteins and oxygen. Correlations between structure and function of the copper oxidases. J. gen. Physiol. 49, 213-252.

Gillette, J.R., Brodie, B.D. \& La Du, B.N. (1957) The oxidation of drugs by liver microsomes: on the role of TPNH and oxygen. J. Pharm. exp. Therap. 119, $532-540$.

Hernandez, O., Aznar, R., Hicks, J.J., Ballesteros, L.M. \& Rosado, S. (1975) Subcellular distribution of trace metals in the normal and in the copper-treated human secretory endometrium. Contraception 11, $451-459$.

Hinckle, P.C., Butow, R.A., Racker, E.F. \& Chance, B. (1967) Partial resolution of the enzymes catalysing oxidative phosphorylation. J. biol. Chem. 242, 5169-5173.

Jenson, P.K. (1966) Antimycin-insensitive oxidation of succinate and reduced nicotinamide-adenine dinucleotide in electron transport particles. I. pH dependency and hydrogen peroxide formation. Biochim. Biophys. Acta 122, 157-166.

Kovalsky, V.M. \& Vorotnitskaya, I.E. (1970) Role of copper and molybdenum in the regulation of the activity of xanthine oxidase and urate oxidase. In Trace Element Metabolism in Animals, pp. 176-178. Ed. G. F. Mills. Livingstone, London.

Loschen, G., Flohe, L. \& Chance, B. (1971) Respiratory chain-linked hydrogen peroxide production in pigeon brain mitochondria. FEBS Letters 8, 261-267.

Lowry, O.H., Rosebrough, H.J., Farr, A.L. \& Randall, R.J. (1951) Protein measurement with the Folinphenol reagent. J. biol. Chem. 193, 265-275.

Menzel, D.B. (1970) Toxicity of ozone, oxygen and radiation. Ann. Rev. Pharmac. 10, 379-394.

Moo-Young, A.J. \& Tatum, H.J. (1974) Copper levels in maternal and fetal tissues of rabbits bearing intrauterine copper wires. Contraception 9, 487-496.

Moo-Young, A.J., Tatum, H.J., Brinson, A.O. \& Hood,
W. (1973) Copper levels in tissues of rhesus monkeys bearing intrauterine or intra-abdominal copper devices. Fert. Steril. 24, 848-853.

Nofre, C. \& Cier, A. (1967) Effect of hydroxyl free radicals on pyrimidine bases. In Electronic Aspects of Biochemistry, pp. 397-414. Ed. B. Pullman. Academic Press, New York.

Okereke, T., Sternleib, J., Morell, A.G. \& Scheinberg, I.H. (1972) Systemic absorption of intrauterine copper. Science, N.Y. 177, 358-360.

Oshino, N. \& Chance, B. (1973) The role of $\mathrm{H}_{2} \mathrm{O}_{2}$ generation in perfused rat liver and the reaction of catalase compound I and hydrogen donors. Archs. Biochim. Biophys. 154, 117-131.

Oster, G.K. (1971) Reaction of metallic copper with biological substrates. Nature, Lond. 234, 153-154.

Oster, G.K. (1972) Chemical reactions of the copper intrauterine device. Fert. Steril. 23, 18-23.

Oster, G. \& Oster, G.K. (1974) Free radical production by metallic copper. Contraception 10, 273-280.

Paul, B. \& Sbarra, A.J. (1968) The role of phagocyte in host-parasite interactions. XII. The direct quantitative measurement of $\mathrm{H}_{2} \mathrm{O}_{2}$ in phagocytizing cells. Biochim. Biophys. Acta 156, 168-178.

Pihl, A. \& Lange, R. (1962) The interactions of oxidized glutathione, cystamine monosulfoxide and tetrathionate with the -SH groups of rabbit muscle D-glyceraldehyde-3-phosphate dehydrogenase. $J$. biol. Chem. 237, 1356-1362.

Ranney, R.E., Nutting, E.F., Hackett, P.L., Rancitelli, L.A., Daniel J.L., Clark, W.J. \& Wheeler, R.G. (1975) Uterine copper distribution in monkeys implanted with copper-carrying intrauterine devices. Fert. Steril. 26, 80-92.

Roubel, W.T. \& Tappel, A.L. (1966) Damage to proteins, enzymes and amino acids by peroxidizing lipids. Archs Biochim. Biophys. 111, 5-8.

Salaverry, G., Mendez, M. Del C., Zipper, J. \& Medel, M. (1973) Copper distribution and localisation in different morphologic components of human endometrium during the menstrual cycle in copper intrauterine contraceptive device wearers. $\mathrm{Am}$. J. Obstet. Gynec. 115, 163-168.

Schneider, W.C. (1948) Intracellular distribution of enzymes. III. The oxidation of octanoic acid by rat liver fractions. J. biol. Chem. 176, 259-266.

Sies, H. \& Chance, B. (1970) Steady-state level of catalase compound $I$ in isolated hemoglobin-free perfused rat liver. FEBS Letters 11, 172-178.

Stimson, M.M. \& Reuter, M.A. (1943) Ultraviolet absorption spectra of nitrogenous hetrocycles. VII. The effect of hydroxy substitutions on the ultraviolet absorption of the series: hypoxanthine, xanthine and uric acid. J. Am. Chem. Soc. 65, 153-155.

Tucker, D. \& Grisolia, S. (1962) Inactivation of muscile triosephosphate dehydrogenase by reduced diphosphopyridine nucleotide at physiological concentrations. J. biol. Chem. 237, 1068-1073.

Received 17 December 1979 